\title{
The mystery of the tiny Urticaceae-feeders: documentation of the first leaf-mining Nepticulidae (Lepidoptera) species from equatorial America associated with Phenax, Boehmeria and Pilea
}

\section{Jonas R. Stonis ${ }^{1^{*}}$, \\ Arūnas Diškus ${ }^{1}$, \\ Andrius Remeikis ${ }^{2}$,}

\author{
Alex K. Monro ${ }^{3}$ \\ ${ }^{1}$ Lithuanian University of Educational \\ Sciences and Baltic-American \\ Biotaxonomy Institute, Studentu St. 39, \\ LT-08106 Vilnius, Lithuania \\ ${ }^{2}$ Institute of Ecology, \\ Nature Research Centre, \\ Akademijos St. 2, \\ LT-08412 Vilnius, Lithuania \\ ${ }^{3}$ Identification and Naming Department, \\ Royal Botanic Gardens, Kew, Richmond, \\ Surrey TW9 3AE, United Kingdom
}

The paper presents the first documentation of Urticaceae-feeding Nepticulidae species in South America and describes four new species: two species feeding on Phenax Wedd. (Stigmella singularia Diškus \& Stonis, sp. nov. and S. lata Diškus \& Stonis, sp. nov.), one species on Boehmeria Jacq. (S. boehmeriphaga Diškus \& Stonis, sp. nov.), and one species on Pilea Lindl. (S. auripurpurata Diškus \& Stonis, sp. nov.); all from the equatorial Andes. In addition, leaf-mines of an unknown Stigmella taxa feeding on Phenax are documented. The newly discovered Urticaceae-feeding Nepticulidae exhibit some morphological and taxonomical diversity: two species groups, Stigmella singularia and S. marmorea, are revealed (the latter is designated in the current paper).

Keywords: the Andes, Boehmeria Jacq., leaf-mines, Nepticulidae, new species, Pilea Lindl., Phenax Wedd., pygmy moths, South America, Stigmella Schrank, Urticaceae

\section{INTRODUCTION}

The eudicot angiosperm family Urticaceae. It is a medium-sized family comprising ca 2,500 species and 50 genera of woody shrubs, succulent herbs, trees and vines that are found on all of

*Corresponding author. E-mail: stonis@leu.lt the world's continents with the exception of Antarctica. They are characterized by the presence of lactifers in the bark which produce a non-milky latex, stipules, and frequently by the presence of crystalline structures in the leaves known as cystoliths. Their flowers are almost always unisexual and consist of a single whorl of tepals and female flowers with a single basal ovule. The family is of 
interest for several reasons: it exhibits great variation in female flower morphology, it is divided between disturbed vegetation and pristine vegetation specialists, and it includes two species-rich genera, each comprising over 500 species, Pilea and Elatostema. The centre of genus diversity is Southeast Asia, whilst the centre of species diversity is the Neotropics, in particular the foothills of the Andes and the Greater Antilles. A taxonomic revision of the family was provided by Weddell (1869) and the most comprehensive phylogeny by Wu et al. (2013).

Leaf-mining Nepticulidae, or pygmy moths. They are a specialized but phylogenetically primitive Lepidoptera family which comprises the smallest moth on Earth. The family was extensively characterized in monographic reviews by Scoble (1983), Johansson et al. (1990), Puplesis (1994), and Puplesis, Diškus (2003), with special reference to South America also by Puplesis, Robinson (2000) and Stonis et al. (2016c). One of the most prominent characteristics of the Nepticulidae is their larval biology. Larvae of pygmy moths mine the green tissue of plants during all instars producing rather conspicuous or highly conspicuous linear or blotch-like leaf-mines. These mines are produced in the leaf lamina, and rarely in other plant organs than leaves (stems, cambium, buds, maple fruit). Being plantminers, Nepticulidae can have a significant impact on their host plants and are often regarded as pests or potential pests (Kuznetzov, Puplesis, 1994; Remeikis et al., 2014). Another pronounced ecological particularity of the Nepticulidae is their high host specificity (stenophagy) with most of the known species either monophagous or strictly oligophagous and rarely broadly oligophagous or disjunctly oligophagous (for the definition of the terms and the predominance of monophagy in Nepticulidae, see Diškus, Stonis (2012) and Puplesis, Diškus (2003)). Host plant specificity represents an issue of importance in ecology, insect-plant interaction, and evolution. In the case of the Nep- ticulidae, however, host specificity remains insufficiently documented, especially so in the tropics and subtropics.

In the earliest stage of research, the majority of Neotropical Nepticulidae have been described without host-plant data, i.e., species descriptions were based on non-reared material. The host plants of only a small proportion of the species were known and include host plants in the Fabaceae (Leguminosae), Malvaceae, Polygonaceae (see Puplesis, Robinson, 2000; Puplesis et al., 2002a, 2002b). The history of Neotropical and Ando-Patagonian Nepticulidae research is provided by Stonis et al (2016c). Recently a first review of Rosaceae-feeding Nepticulidae (Stonis et al., 2016b, 2016d) and a few other papers dealing with new host-plant data (Stonis et al., 2015, 2016a, ect.) have focused on Nepticulidae. Currently a substantial review on Lamiaceae-feeding Nepticulidae is in progress (Stonis et al., in preparation).

To date no Urticaceae-feeding Nepticulidae have been documented from the Neotropics, and little data is available from other regions of the world. Here we document the first observations of Urticaceae-feeding Nepticulidae from the Andes, South America, together with all previous records of the Urticaceae-feeding Nepticulidae worldwide (Fig. 1). In doing so we describe four new Stigmella species trophically associated with Phenax, Boehmeria, and Pilea. We also document leaf-mines from Phenax hirtus, which belong to an unknown Urticaceaefeeding taxon.

\section{MATERIALS AND METHODS}

Descriptions of new species are based on material deposited in the collection of the Zoological Museum, Natural History Museum of Denmark in Copenhagen, Denmark, collected in Ecuador by Arūnas Diškus and Jonas Rimantas Stonis, formerly by Rimantas Puplesis, as part of various research projects in collaboration with Ecuadorian partners. This included an initial project in 1999 by Puplesis and S. R. Hill together with Professor Giovanni Onore, former professor at 


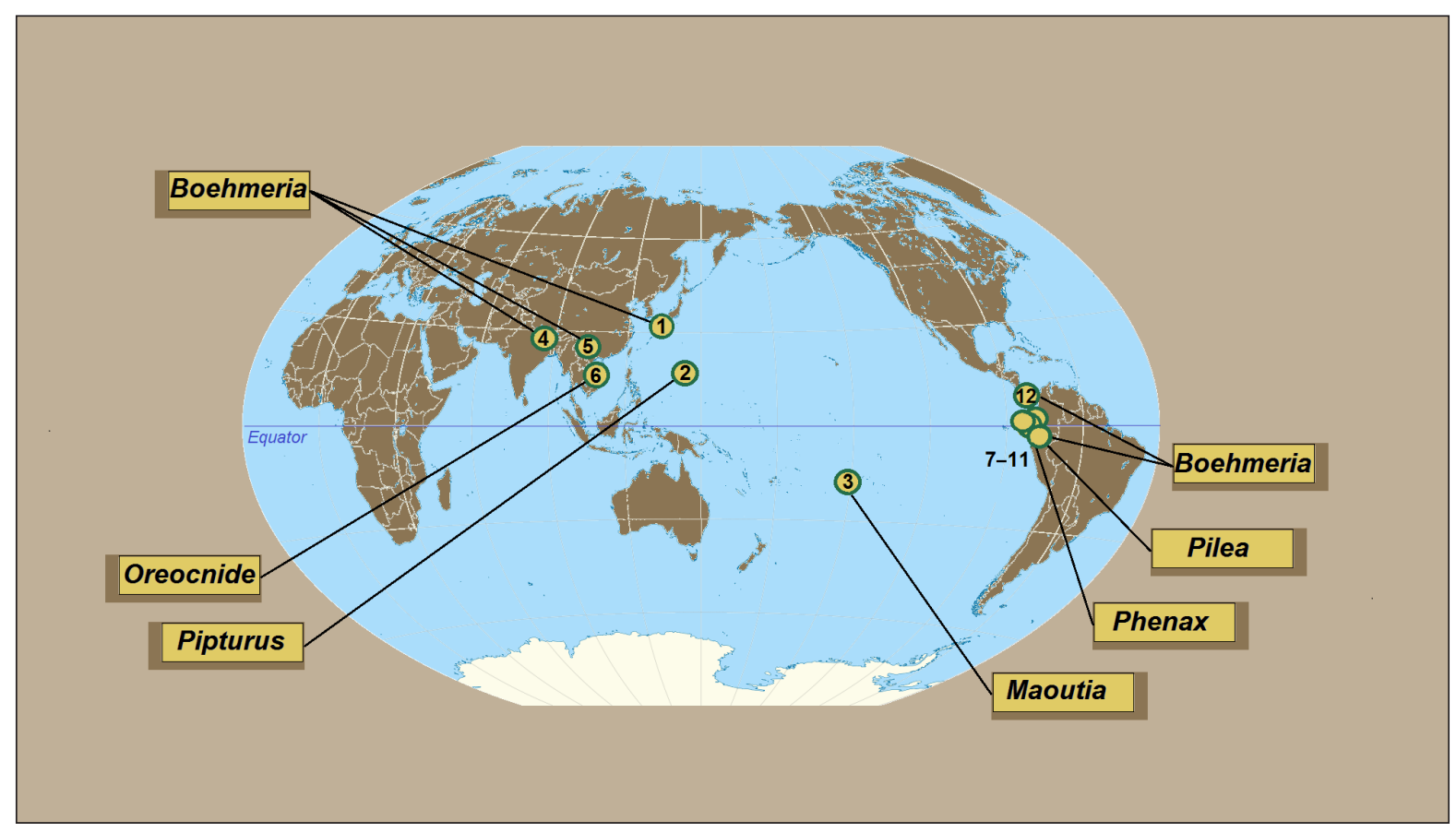

Fig. 1. Currently known records of Nepticulidae trophically associated with various genera of Urticaceae: 1 - Stigmella boehmeriae Kemperman \& Wilkinson on Boehmeria nipononivea and B. spicata from Kyushu, Japan (see Kemperman, Wilkinson, 1985); 2 - S. ebbenielseni van Nieukerken \& van den Berg on Pipturus argenteus from Guam and Mariana Islands; 3 - documented leaf-mines of unidentified Stigmella taxon on Maoutia australis from Tahiti, Society Islands, French Polynesia (for details on the latter two records see van Nieukerken, van den Berg, 2003); 4-6 - three recognized but undescribed Stigmella species on Boehmeria and Oreocnide from Nepal and Vietnam (see van Nieukerken, van den Berg, 2003); 7 - S. singularia Diškus \& Stonis, sp. nov. on Phenax hirtus from Pichincha Province, Ecuador; 8 - S. lata Diškus \& Stonis, sp. nov. on Phenax hirtus from Pichincha Province, Ecuador; 9 - S. boehmeriphaga Diškus \& Stonis, sp. nov. on Boehmeria sp. from Tungurahua Province, Ecuador; 10 - S. auripurpurata Diškus \& Stonis, sp. nov. on Pilea sp. from Pichincha and Chimborazo Provinces, Ecuador; 11 - documented specific leaf-mines of undescribed Stigmella taxon on Phenax hirtus (see Fig. 64 of the current paper) from Pichincha Province, Ecuador; 12 - an unknown, probably Stigmella taxon tracked on herbaria specimen of Boehmeria ulmipholia collected in Panama in 1935 (see Discussion)

the Pontifical Catholic University of Ecuador, Quito, Ecuador.

Collecting methods and protocols for species identification and description are outlined in Puplesis (1994); Puplesis, Robinson (2000); and Puplesis, Diškus (2003). After maceration of the abdomen in $10 \% \mathrm{KOH}$ and subsequent cleaning, male genital capsules were removed from the abdomen and mounted ventral side uppermost. The phallus was removed and mounted in Euparal separately but on the same genitalia slide. Abdominal pelts and female genitalia were stained with Chlorazol Black
(Direct Black 38/Azo Black) (for a detailed description of the method see Stonis et al., 2014).

Permanent slides were photographed and studied using a Leica DM2500 microscope and Leica DFC420 digital camera. The descriptive terminology of morphological structures follows Puplesis, Robinson (2000), except for the term "aedeagus", which is referred here as "phallus", and the term "cilia", which is referred here as "fringe".

Institutional abbreviation used in the text: ZMUC - Zoological Museum, University of Copenhagen, Denmark. 


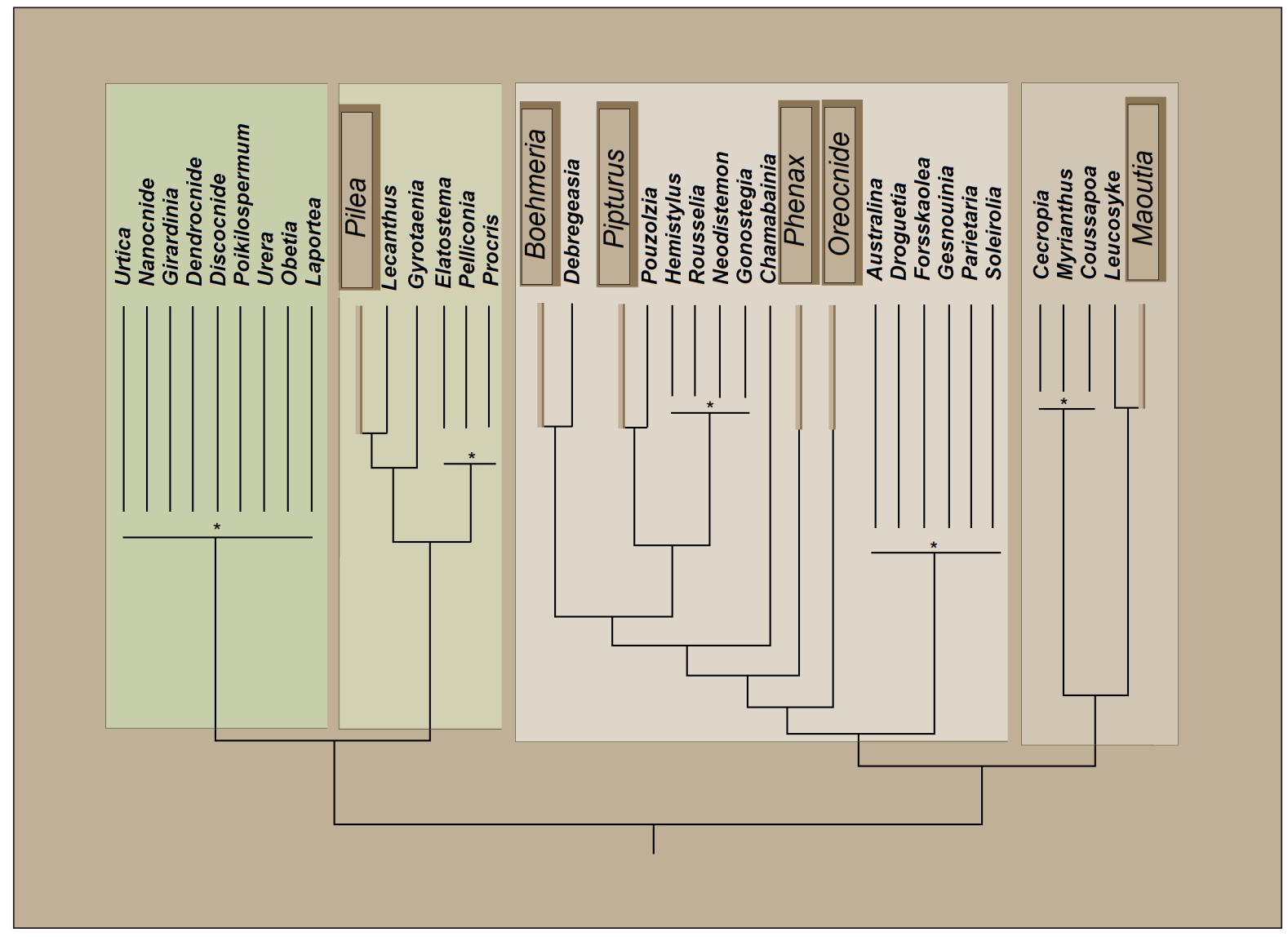

Fig. 2. Urticaceae clades engaged by leaf-mining Nepticulidae (simplified phylogeny after Wu et al., 2013. Note: this is not an ultrametric tree) ${ }^{\star}$ - for detailed relationships of the clades see Wu et al., 2013

\section{RESULTS}

\section{Taxonomy of new Nepticulidae species} associated with plants from Urticaceae The Stigmella singularia species group Diagnostics: forewing varied, speckled or with one fascia. In male genitalia, phallus sometimes with small apical spines and always with many loose, large cornuti; valva with one apical process which may be very pronounced; transtilla with or without small sublateral processes, only occasionally these processes are long; uncus with one or two caudal lobes; gnathos with two caudal processes which are often closely juxtaposed, occasionally merged into one lobe-like caudal process; vinculum small to large (occassionally very large), with small to large lateral lobes, often lateral lobes of vinculum angular. Currently the group comprises ca. 16 species from the Andes of Ecuador and Peru: only six species are currently described and the remainder undescribed (Stonis et al. in prep.). The species are trophically associated with three plant families (Urticaceae, Lamiaceae, and Asteraceae), but Lamiaceae feeders strongly predominate. Leaf-mines are often combined, characterized by abruptly widened, blotch-like distal parts, however, sometimes the mines remain rather slender or widening gradually in their distal part.

\section{Stigmella singularia Diškus \& Stonis, sp. nov.}

Type material. Holotype: $\hat{\sigma}$, ECUADOR: Pichincha Province, $11 \mathrm{~km}$ NW Alóag, $0^{\circ} 26^{\prime}$ 48"S, 78³7'32"W, elevation $3150 \mathrm{~m}$, mining larvae on Phenax hirtus (Sw.) Wedd. (Urticaceae), 14.i.2005, field card no. 4816, A. Diškus

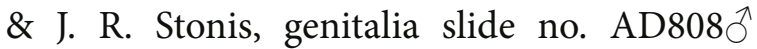
(ZMUC). Paratypes: $1 \hat{\jmath}, 1$, same label data 
as holotype, genitalia slides nos. AD695 $\widehat{\jmath}$ (from adult in pupal skin), AD809 9 (ZMUC).

Diagnosis. The combination of a pointed valva and a unique set of cornuti distinguishes S. singularia sp. nov. from all other Stigmella species; the host plant Phenax Wedd. (Urticaceae), shared with the most similar and probably most closely related S. lata sp. nov., also makes this species distinctive.
Male (Figs. 10, 11). Forewing length about $2.3 \mathrm{~mm}$; wingspan about $5.1 \mathrm{~mm}$. Head: palpi golden cream to grey; frontal tuft bright orange; collar brown with golden gloss and purple iridescence; scape golden cream; antenna slightly longer than half the length of forewing; flagellum with 38-39 segments, dark grey-brown with little golden gloss on the upper side and underside. Thorax and tegula golden brown,

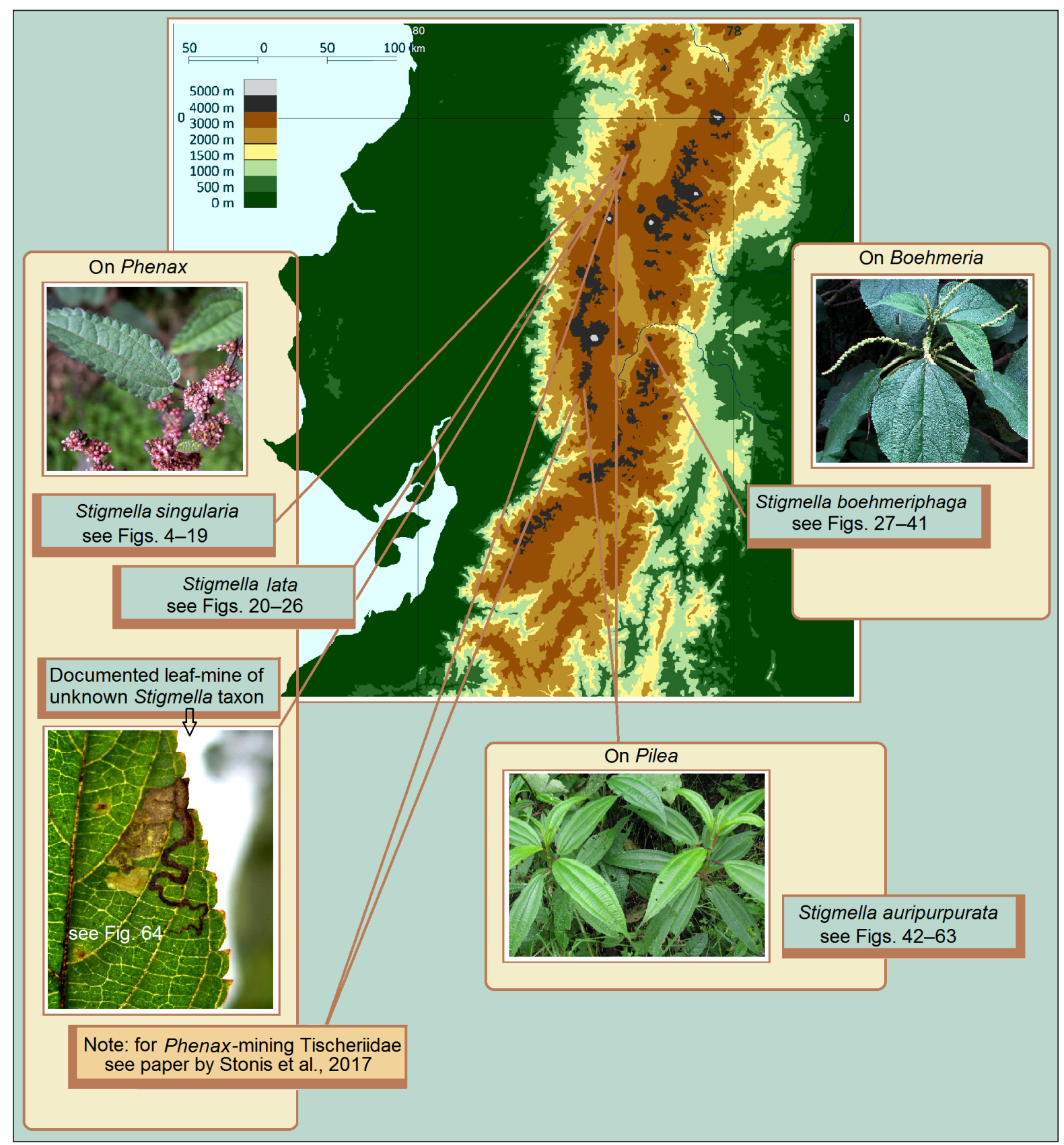

Fig. 3. Current records of the Urticaceae-feeding Nepticulidae from South America 

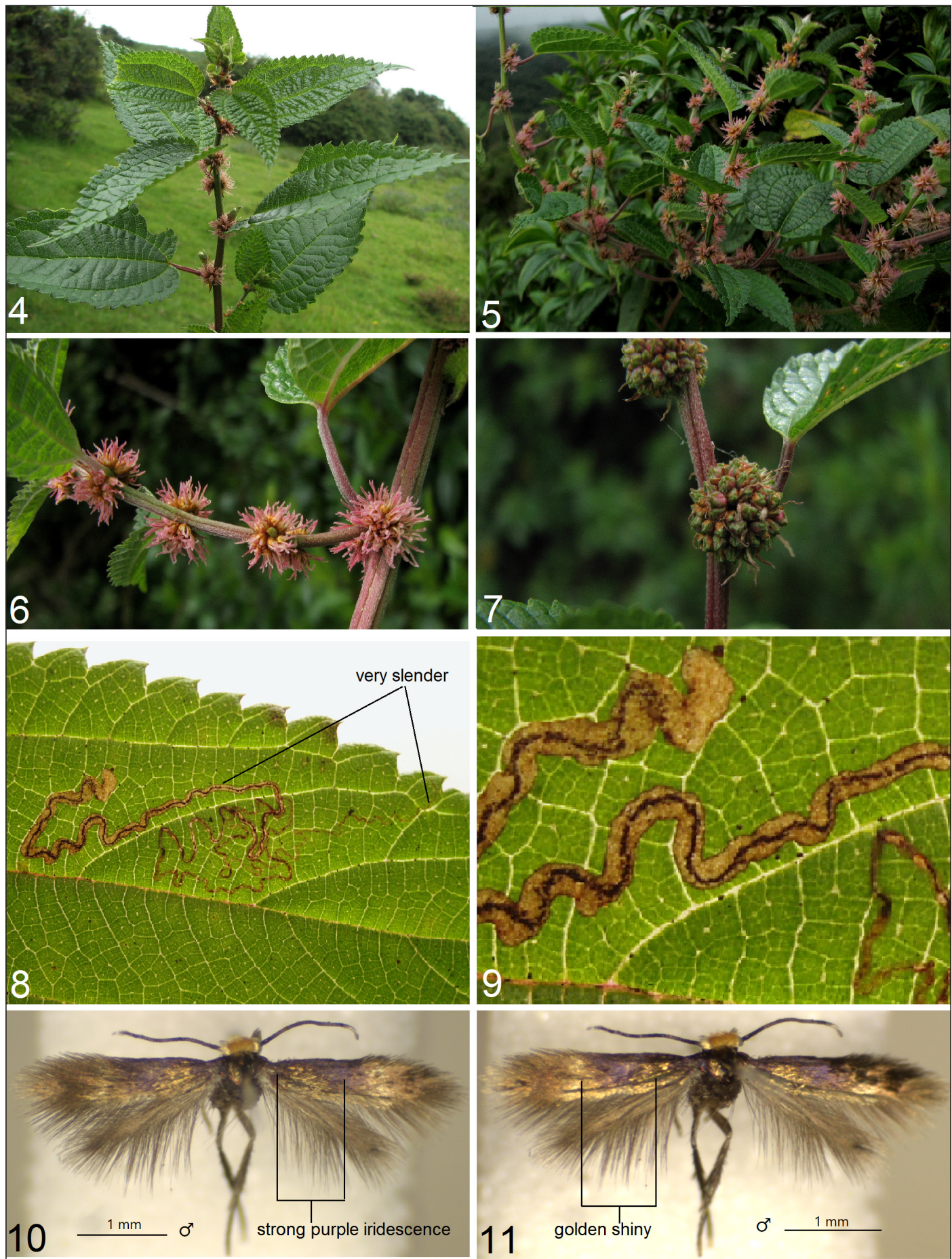

Figs. 4-11. Stigmella singularia Diškus \& Stonis, sp. nov. 4-7 - host plant Phenax hirtus (Sw.) Wedd.; 8, 9 - leaf-mine; 10, 11 - male adult, holotype (ZMUC)

shiny, with strong purple and blue iridescence. Forewing shiny golden brown with very strong purple and blue iridescence on large costal and middle area; fascia very weakly developed, distinctly postmedian, golden shiny; apex of fore- wing brown with golden gloss and little purple iridescence; fringe brown with golden gloss; underside of forewing dark grey-brown to almost black, without spots. Hindwing dark greybrown, with little golden gloss on upper side 


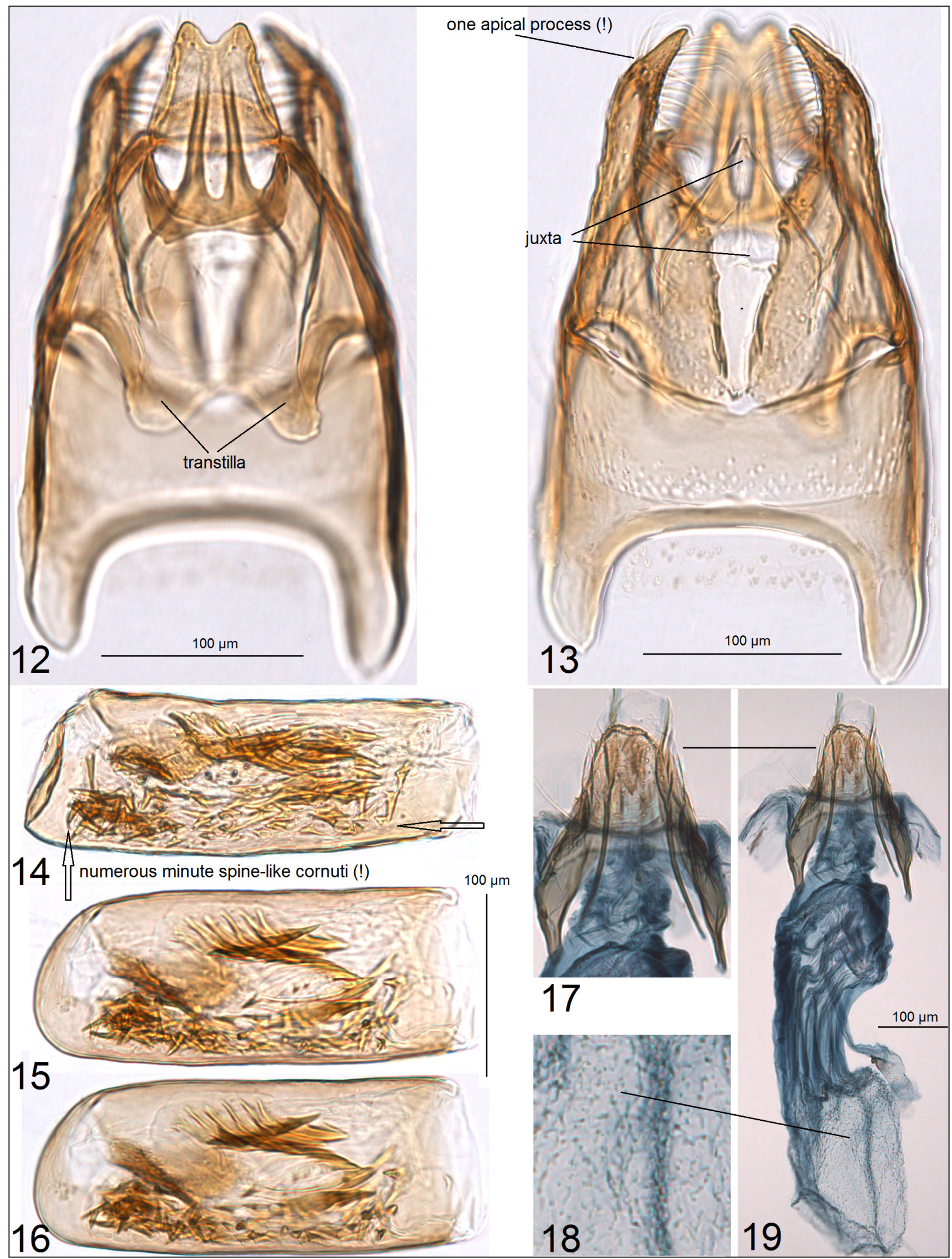

Figs. 12-19. Genitalia of Stigmella singularia Diškus \& Stonis, sp. nov. 12, 13 - holotype, genitalia slide no. AD808, capsule with phallus removed; 14 - same, phallus; 15, 16 - paratype, genitalia slide no. AD695, phallus; 17 - paratype, genitalia slide no. AD809, female genitalia, apophyses; 18 - same, pectinations on corpus bursae; 19 - same, general view (ZMUC) 
and underside, without spots; its fringe brown with some golden gloss. Legs grey-brown with light to strong purple iridescence on upper side and underside. Abdomen black-brown with some purple iridescence on upper side, dark grey, glossy, with little purple iridescence on underside; genital plates fuscous; anal tufts very short, indistinctive, black-brown.

Female. Similar to male.

Male genitalia (Figs. 12-16). Capsule a little longer $(320-340 \mu \mathrm{m})$ than wide $(190-200 \mu \mathrm{m})$. Uncus with two pointed lobes. Gnathos with two long caudal processes and slender central plate. Valva $195 \mu \mathrm{m}$ long, $70-80 \mu \mathrm{m}$ wide, with one pointed apical process; transtilla with triangular or rounded corners, without distinctive sublateral processes. Juxta mostly membranous, caudally pointed and little thickened (Fig. 13). Vinculum short, with rather slender and long lateral lobes. Phallus (Figs. 14-16) 240-245 $\mu \mathrm{m}$ long, 80-95 $\mu \mathrm{m}$ wide; vesica with a compact group of large spine-like cornuti and numerous minute cornuti.

Female genitalia (Figs. 17-19). Total length about $790 \mu \mathrm{m}$. Anterior and posterior apophyses almost equal in length, however, due to some distortion of slide AD809, the anterior apophyses look longer (Fig. 17). Vestibulum without sclerites. Corpus bursae with very large, heavily folded distal part and small (185 $\mu \mathrm{m}$ long) basal body; signa absent; pectinations distinctive, comb-like. Accessory sac short but wide, heavily folded; ductus spermathecae without coils but with a tiny sclerite. Abdominal tip almost rounded or truncated.

Bionomics (Figs. 4-9). Host plant: Phenax hirtus (Sw.) Wedd. (Urticaceae) (Figs. 4-7). Larvae mine in leaves in January and, judging from observed numerous old (empty) leafmines, in December. Leaf-mine (Figs. 8, 9) as a contorted or sinuous very long and narrow gallery with a slender line of black-brown frass. Exit slit on the upper side of the leaf. According to the "Formula of Determining Abundance and Occurrence of Leaf-Miners" (see Diškus, Stonis 2012: 52-54), Stigmella singularia is a rare species: sparse mining of the new species was observed in a single locality of the equatorial Andes in Ecuador.

Distribution (Figs. 1, 3). This species occurs in the Ecuadorian Andes in tropical montane and cloud forests at elevations of ca $3100 \mathrm{~m}$.

Etymology. The species name is derived from the Latin singularia (singular) in reference to the single apical process on valva of the male genitalia.

\section{Stigmella lata Diškus \& Stonis, sp. nov.}

Type material. Holotype: $\hat{\sigma}$, ECUADOR: Pichincha Province, $11 \mathrm{~km}$ NW Alóag, 0²6’ 48"S, 78³7'32"W, elevation $3150 \mathrm{~m}$, mining larvae on Phenax hirtus (Sw.) Wedd. (Urticaceae), 26.ii.2007, field card no. 4893, A. Diškus \& J. R. Stonis, genitalia slide no. AD776 (from adult in pupal skin) (ZMUC).

Diagnosis. Belongs to the $S$. singularia group. The combination of a wide capsule with very short lobes of vinculum and a unique set of cornuti distinguishes $S$. lata sp. nov. from the most similar and probably closely related S. singularia sp. nov.; the host-plant Phenax Wedd. (Urticaceae), shared with S. singularia, also makes this species distinctive among other Stigmella (except for S. singularia).

Male (See Remarks).

Female. Unknown.

Male genitalia (Figs. 24-26). Capsule $200 \mu \mathrm{m}$ wide, $250 \mu \mathrm{m}$ long. Uncus with four caudal papillae. Gnathos with two long caudal processes and slender central plate. Valva 190$195 \mu \mathrm{m}$ long, 80-90 $\mu \mathrm{m}$ wide, with one pointed apical process; transtilla with triangular or rounded corners, without distinctive sublateral processes. Juxta membranous, indistinctive. Vinculum short, with very short lateral lobes. Phallus (Fig. 26) $280 \mu \mathrm{m}$ long, 110-125 $\mu \mathrm{m}$ wide; vesica with numerous large and long spine-like cornuti and numerous short ones.

Bionomics (Figs. 20-23). Host plant: Phenax hirtus (Sw.) Wedd. (Urticaceae) (Figs. 4-7). Larva yellow with dark green to ochreous brown intestine and dark brown head; mines in leaves in February and, judging from observed old (empty) leaf-mines, in January. Leafmine (Figs. 20-23) as a contorted or sinuous 


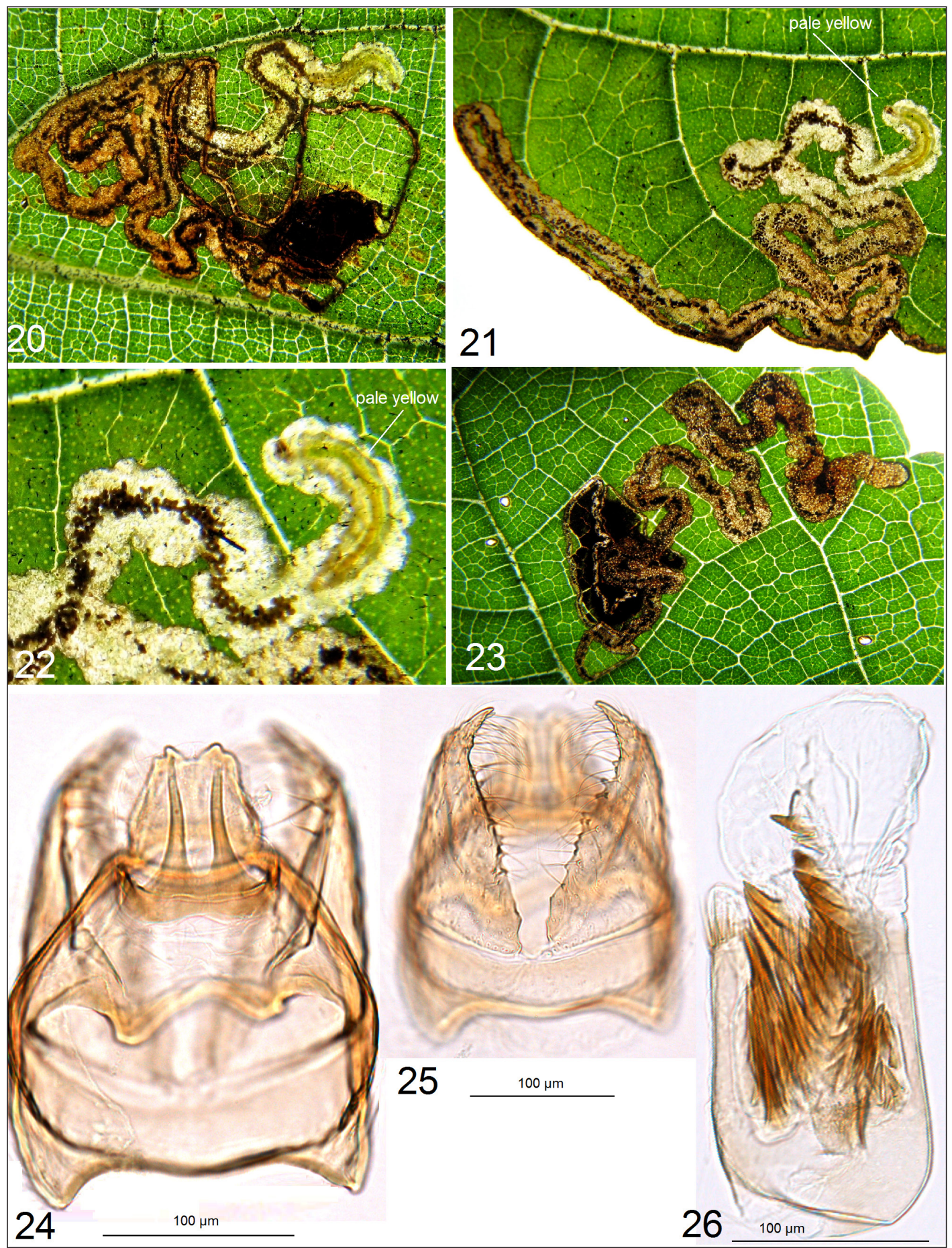

Figs. 20-26. Stigmella lata Diškus \& Stonis, sp. nov. 20-23 - leaf-mines on Phenax hirtus (Sw.) Wedd.; 24, 25 - holotype, male genitalia, slide no. AD776, capsule with phallus removed; 26 - same, phallus (ZMUC)

gallery with a line of dark brown frass. Exit slit on the upper side of the leaf. According to the "Formula of Determining Abundance and Occurrence of Leaf-Miners" (see Diškus, Stonis
2012: 52-54), Stigmella lata is not a rare species: abundant mining of the new species was observed, however, only in a single locality of the equatorial Andes in Ecuador. 
Distribution (Figs. 1, 3). Stigmella lata occurs in the Ecuadorian Andes in tropical montane and cloud forests at altitudes ca. $3200 \mathrm{~m}$.

Etymology. The species name is derived from the Latin latus (wide, wider) in reference to the detected differences of $S$. lata from the most similar S. singularia: the wider, almost rounded capsule, wider uncus, and the presence of wide cornuti (instead of slender, minute ones in S. singularia).

Remarks. Stigmella lata is a distinctive species. Because of the urgency to name this species for further taxonomic analysis, S. lata was described on the basis of the specific male genitalia and leaf-mines alone. Details of adult scaling remain unknown because the currently available holotype specimen was dissected from adult in a pupal skin and no pinned specimen was preserved.

\section{Stigmella boehmeriphaga Diškus \& Stonis, sp. nov.}

Type material. Holotype: $\hat{\jmath}$, ECUADOR: Tungurahua Province, Baños, $1^{\circ} 23^{\prime} 44^{\prime \prime}$ ', 78 26' 14 "W, elevation $1900 \mathrm{~m}$, mining larvae on Boehmeria sp. (Urticaceae), 11.ii.2007, field card no. 4854, A. Diškus \& J. R. Stonis, genitalia

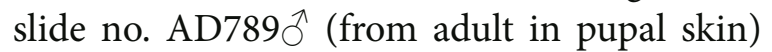
(ZMUC). Paratypes: $1 \hat{\partial}, 1$ \&, same label data as holotype, genitalia slides nos. AD788 $\hat{\circ}$, AD873 9 (both from adult in pupal skin) (ZMUC).

Diagnosis. Belongs to the $S$. singularia group. The combination of lateral spine-like processes of phallus, a long uncus, large lobes of vinculum, and a unique set of cornuti distinguishes S. boehmeriphaga sp. nov. from all other Stigmella species; the host-plant Boehmeria (Urticaceae) also makes this species distinctive.

Male (Fig. 32). Forewing length about $1.8 \mathrm{~mm}$; wingspan about $4.1 \mathrm{~mm}$. Head: palpi grey cream; frontal tuft pale orange; collar and scape golden cream; antenna longer than half the length of forewing; flagellum with about 25 segments, dark grey-brown with distinctly paler tip (six distal segments whitish cream). Thorax and tegula dark olive grey with golden gloss. Forewing olive with strong golden gloss, little purple iridescence at the base but strong purple and blue iridescence before fascia and on apex; fascia postmedian, wide, golden shiny; fringe olive grey. Scaling of hindwing unknown (see Remarks). Legs fuscous grey, with little purple iridescence. Abdomen dark grey on upper side, grey on underside.

Female. Similar to male.

Male genitalia (Figs. 33-40). Capsule 300$305 \mu \mathrm{m}$ long, $180-190 \mu \mathrm{m}$ wide. Uncus long, with four tiny caudal lobes. Gnathos with two long caudal processes and a large, medially excavated central plate. Valva 170-185 $\mu \mathrm{m}$ long, 70-75 $\mu \mathrm{m}$ wide, with two slender apical processes; transtilla with triangular or rounded corners, without distinctive sublateral processes. Juxta membranous, indistinctive. Vinculum with large lateral lobes. Phallus (Figs. 35, 40) about $210 \mu \mathrm{m}$ long, 90-105 $\mu \mathrm{m}$ wide, with two long, spine-like lateral slerites (Fig. 40); vesica with many large spine-like cornuti and numerous tiny cornuti (Fig. 35).

Female genitalia (Fig. 41). Anterior and posterior apophyses almost equal in length; anterior ones wide but gradually arrowed distally. Vestibulum without sclerites. Abdominal tip almost rounded. Otherwise unknown.

Bionomics (Figs. 27-31). Host plant: Boehmeria Jacq. (Urticaceae) (Figs. 29, 30). Larva mines in leaves in February and, judging from observed old (empty) leaf-mines, in January. Leaf-mine (Fig. 31) as a sinuous slender but gradually widening gallery with a central line of brown-black frass. Exit slit on the upper side of the leaf. Cocoon pale ochre beige; length 2.3-2.5 mm, maximal width $1.0-1.1 \mathrm{~mm}$. According to the "Formula of Determining Abundance and Occurrence of Leaf-Miners" (see Diškus, Stonis 2012: 52-54), Stigmella boehmeriphaga is a rare species: sparse mining of the new species was observed only in a single locality of the equatorial Andes in Ecuador.

Distribution (Figs. 1, 3). This species occurs in the Ecuadorian Andes in tropical montane forests at altitudes ca. $1900 \mathrm{~m}$.

Etymology. The species name is derived from the name of the host-plant genus Boehmeria and Latin phaga (an eater). 

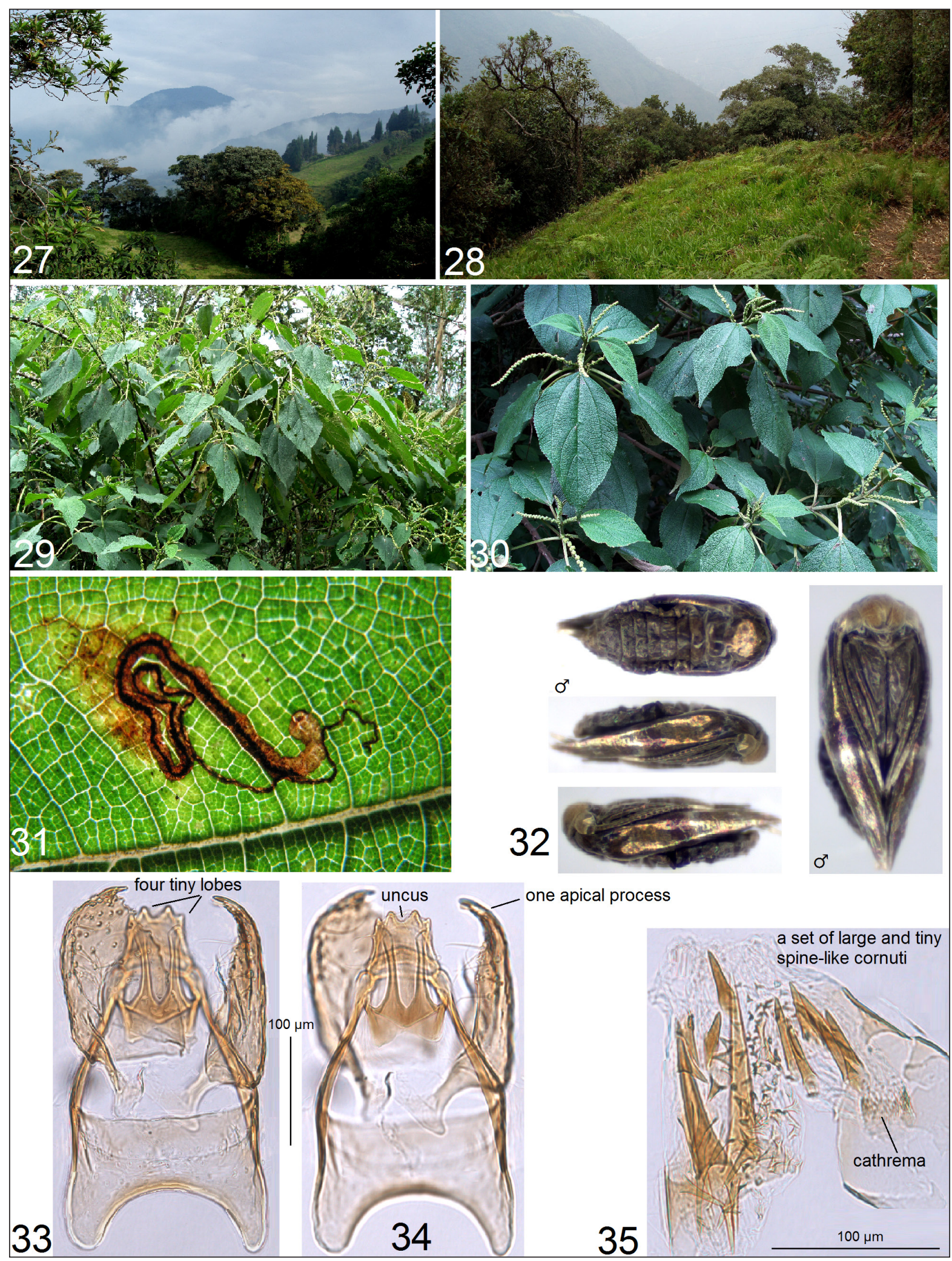

one apical process
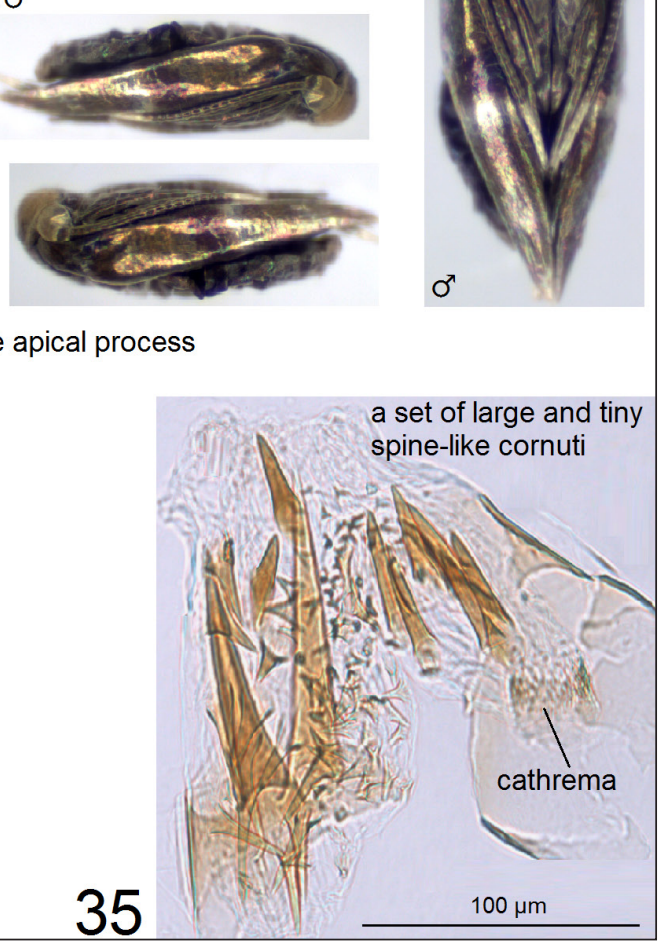

Figs. 27-35. Stigmella boehmeriphaga Diškus \& Stonis, sp. nov. 27, 28 - habitat, tropical montane forest, Baños, 1²3'44”S, 78²6'14”W, Tungurahua Province, elevation 1900 m; 29, 30 - host plant Boehmeria sp.; 31 - leaf-mine; 32 - fully developed pupa; 33, 34 - paratype, male genitalia, slide no. AD788, capsule with phallus removed; 35 - same, cornuti (ZMUC) 


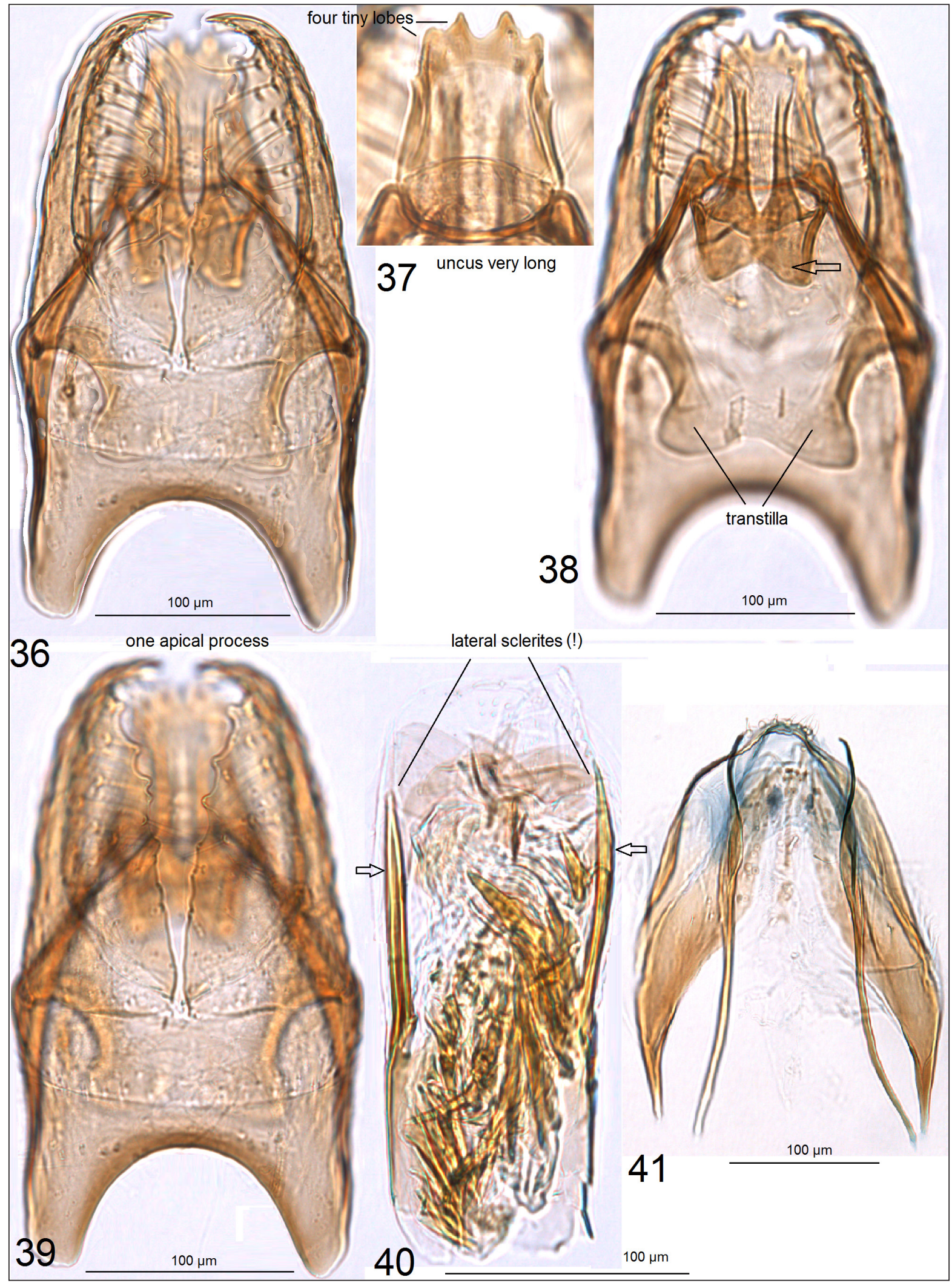

Figs. 36-41. Genitalia of Stigmella boehmeriphaga Diškus \& Stonis, sp. nov. 36-39 - holotype, male genitalia, slide no. AD789, capsule with phallus removed; 40 - same, phallus; 41 - paratype, female genitalia, slide no. AD873, apophyses (ZMUC) 
Remarks. Stigmella boehmeriphaga represents a distinctive species. All currently available type series specimens were dissected from adults in a pupal skin, however, no pinned specimens were preserved.

\section{The Stigmella marmorea species group (des- ignated here)}

Diagnostics: forewing varied: speckled or with one-two fasciae, occasionally glossy, without fascia; at least one species is known with distinctive androconia on abdomen. In male genitalia, phallus sometimes with very small to large apical spines and always with many loose large, mostly horn-like, cornuti; valva with two apical processes; transtilla with or without very small sublateral processes; uncus often with four caudal papillae, sometimes bilobed; gnathos with two caudal processes; vinculum large (occassionally very large), with small to large lateral lobes. Currently the group comprises of about 29 species from the Andes of Colombia, Ecuador, Peru, Bolivia, Chile and Argentina: 26 of the species are described, others remain undescribed (Stonis et al. in prep.). Trophically, the species are associated with at least five plant families: Euphorbiaceae, Rosaceae, Urticaceae, Lamiaceae, and Asteraceae. Leaf-mines as rather slender galleries, occasionally with distal parts resembling blotches.

\section{Stigmella auripurpurata Diškus \& Stonis, sp. nov.}

Type material. Holotype: $\hat{\sigma}$, ECUADOR: Pichincha Province, $11 \mathrm{~km}$ NW Alóag, $0^{\circ} 26^{\prime} 45^{\prime \prime}$, 78³7'34"W, elevation $3090 \mathrm{~m}$, mining larvae on Pilea Lindl. (Urticaceae), 18.xi.2007, field card nos. 4929, A. Diškus, genitalia slide no. AD822 ${ }^{\Uparrow}$ (ZMUC). Paratypes: 1 ภ, 3 ㅇ, same locality as holotype, mining larvae on Pilea 26.ii.2007 and 18.xi.2007, field card nos. 4901, 4929, A. Diškus, genitalia slide nos. AD826 $\widehat{ }$

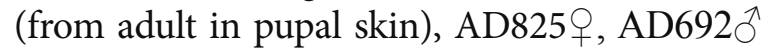

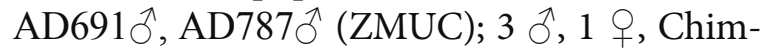
borazo Province, ca. $30 \mathrm{~km}$ NE Pallatanga, $1^{\circ} 51^{\prime 2} 26^{\prime \prime} \mathrm{S}, 78^{\circ} 53^{\prime} 48^{\prime \prime} \mathrm{W}$, elevation $2945 \mathrm{~m}$, mining larva 12.xi.2007, A. Diškus, genitalia slide

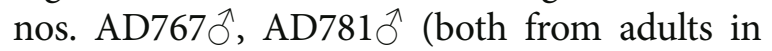
pupal skin), AD823 9 (ZMUC).
Diagnosis. The combination of a valva with two short apical processes and a unique set of cornuti distinguishes $S$. auripurpurata sp. nov. from all other Stigmella species; the host plant Pilea Lindl. (Urticaceae) and the combined leaf-mines with blotch-like distal parts also make this species distinctive.

Male (Figs. 49, 51, 52). Forewing length 2.1-2.5 mm; wingspan 4.8-5.6 mm. Head: palpi golden cream to whitish cream; frontal tuft bright orange to dark orange, occasionally pale orange to orange cream; collar fuscous, golden glossy with little to strong purple iridescence; scape golden cream, very glossy; antenna significantly longer than half the length of forewing; flagellum with 35-38 segments, fuscous with golden gloss on upper side and underside. Thorax and tegula golden brown to fuscous, shiny, with purple iridescence. Forewing brown, with very strong golden gloss and some purple to very strong purple iridescence (purple iridescence may significantly vary); sometime forewing also with blue iridescence along with the purple one; fascia golden shiny, median; apex of forewing brown, despite that it may look golden shiny at a certain angle of view, without spot or fascia; fringe brown to pale brown, with golden gloss; underside of forewing black-brown to greybrown, without spots. Hindwing brown to pale brown, with golden gloss on upper side and underside, without spots or androconia; its fringe brown. Legs brown with golden gloss and some purple iridescence on upper side, pale brown to silver grey on underside. Abdomen dark brown to black-brown on upper side, dark brown on underside except median area which remains golden cream; genital segments grey, glossy; anal tufts very short, black-brown to black, occasionally pale grey.

Female (Figs. 50, 53). Similar to male. Forewing length about $2.8 \mathrm{~mm}$; wingspan about $6.3 \mathrm{~mm}$. Genital segments almost white on underside.

Male genitalia (Figs. 54-61). Capsule little longer $(300-320 \mu \mathrm{m})$ than wide $(245-255 \mu \mathrm{m})$. Uncus with four small but very distinctive caudal lobes. Gnathos with two caudal processes and rather slender central plate. Valva 220-230 $\mu \mathrm{m}$ 


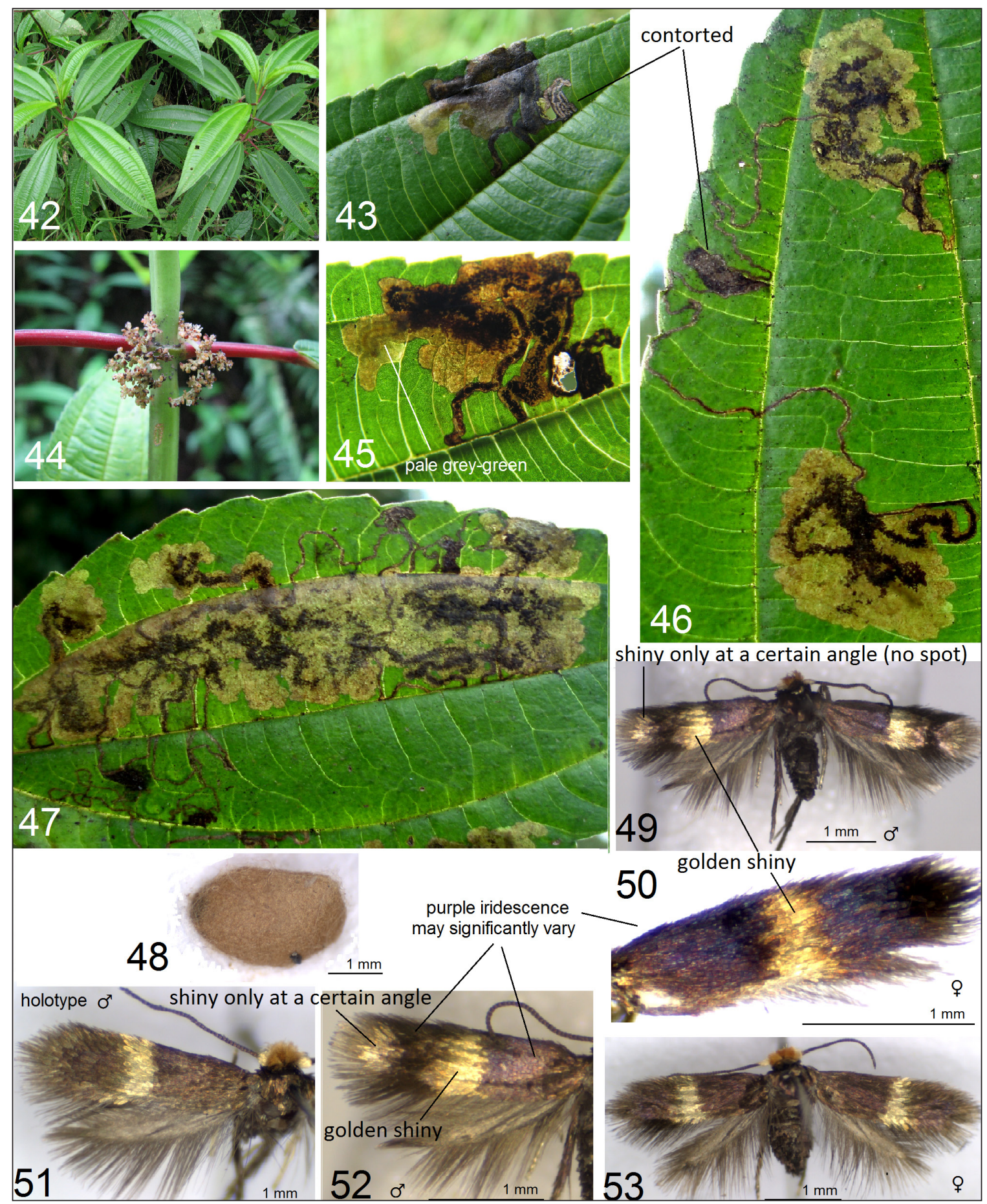

Figs. 42-53. Stigmella auripurpurata Diškus \& Stonis, sp. nov. 42,44 - host plant Pilea sp.; 43, 4547 - leaf-mines on Pilea sp.; 48 - cocoon; 49 - paratype, male adult; 50 - same, forewing of female adult; 51 - holotype, male adult, 52 - paratype, male adult; 53 - same, female adult (ZMUC)

long, 70-85 $\mu \mathrm{m}$ wide, with two small apical processes; transtilla angular (Figs. 55, 56), without sublateral processes. Juxta membranous, caudally triangular. Vinculum short, with very small lateral lobes. Phallus (Figs. 58-61) 290-340 $\mu \mathrm{m}$ long, 105-145 $\mu \mathrm{m}$ wide; vesica with a group of large spine-like cornuti and numerous minute cornuti. 


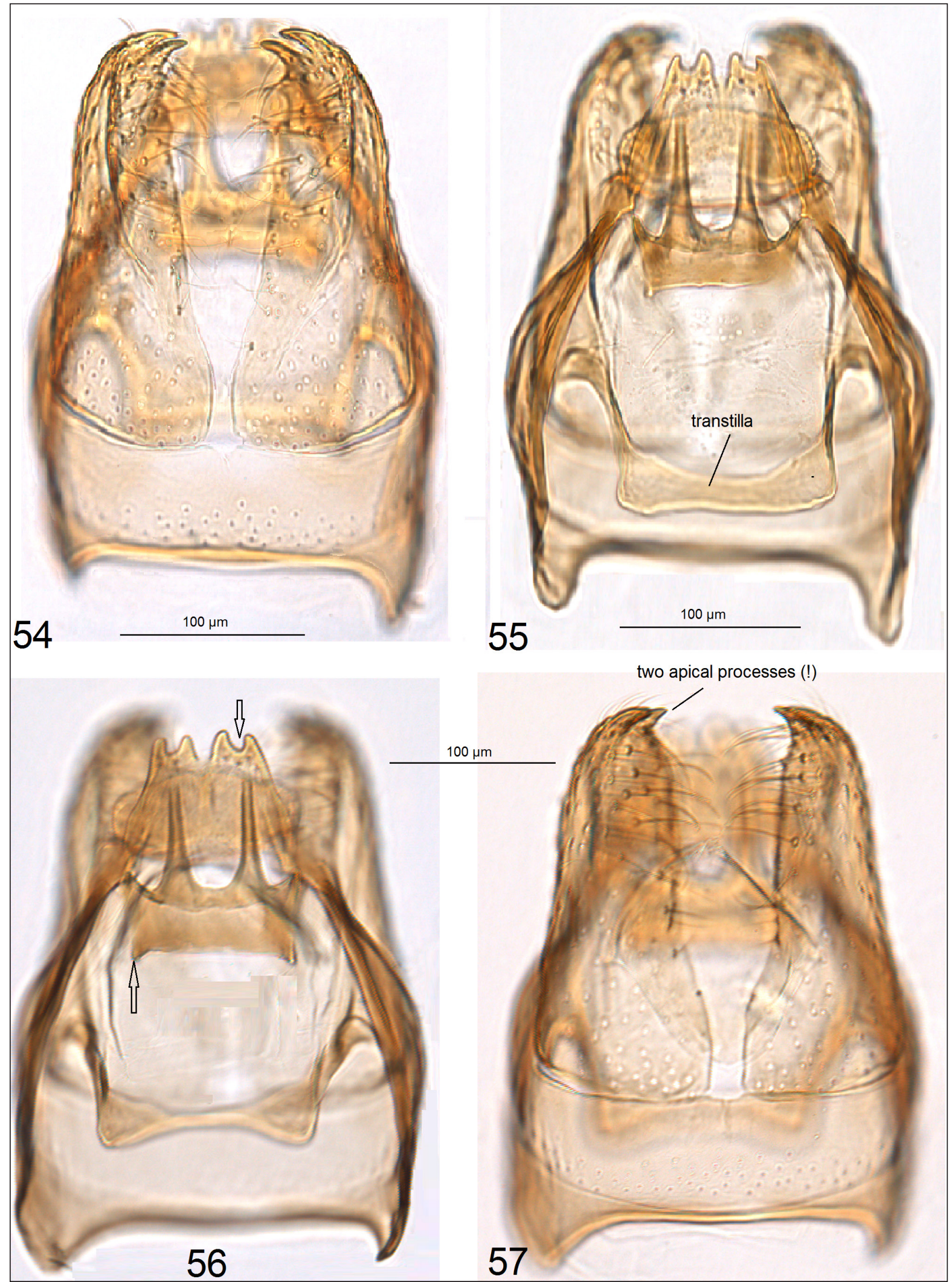

Figs. 54-57. Male genitalia of Stigmella auripurpurata Diškus \& Stonis, sp. nov., capsule with phallus removed. 54 - paratype, genitalia slide AD691; 55 - holotype, genitalia slide AD822; 56, 57 - paratype, genitalia slide no. AD767 (ZMUC) 


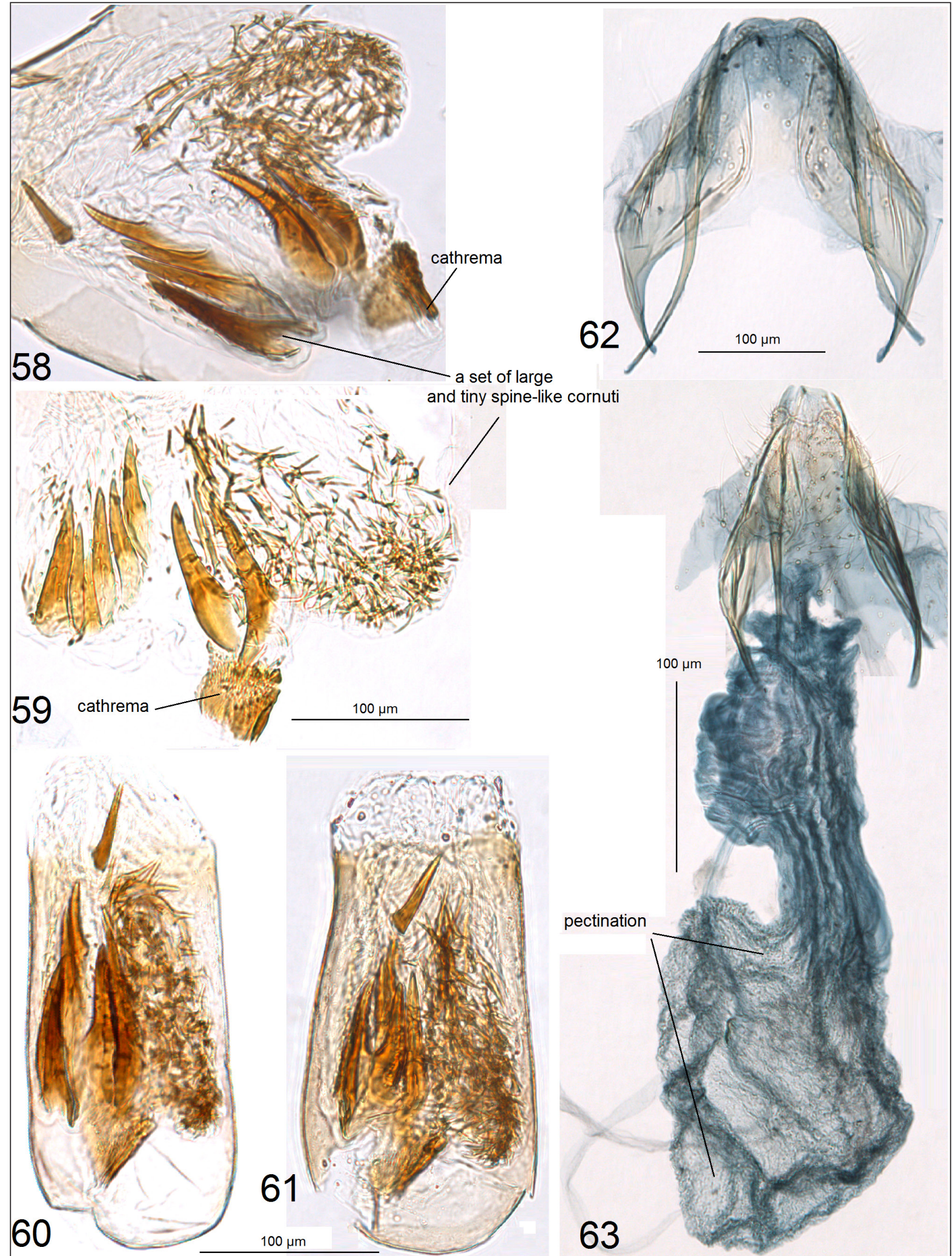

Figs. 58-63. Genitalia of Stigmella auripurpurata Diškus \& Stonis, sp. nov. 58 - paratype, male genitalia, cornuti, genitalia slide no. AD767; 59 - same, genitalia slide AD692; 60 - phallus, paratype, genitalia slide AD767; 61 - same, holotype, genitalia slide no. AD822; 63 - paratype, female genitalia, slide no. AD825 (ZMUC) 
Female genitalia (Figs. 62, 63). Total length about $450 \mu \mathrm{m}$. Anterior and posterior apophyses almost equal in length (Fig. 62). Vestibulum without sclerites. Corpus bursae with large, very heavily folded distal part and $190 \mu \mathrm{m}$ long, $130 \mu \mathrm{m}$ wide basal body; signa absent; pectinations distinctive. Accessory sac short but wide, very heavily folded; ductus spermathecae without coils. Abdominal tip narrowed and truncated.

Bionomics (Figs. 42-48). Host plant: Pilea Lindl. (Urticaceae) (Figs. 42, 44). Larva mines in leaves in February and November. Leaf-mine (Figs. 43, 45-47) starts as a slender sinuous gallery with a line of brownish black frass; further on the gallery abruptly widens to a large, irregularly shaped blotch with scattered black frass. Exit slit on the upper side of the leaf. Cocoon (Fig. 48) ochre beige; length $2.4-3.5 \mathrm{~mm}$, maximal width 2.0-2.4 mm. According to the "Formula of Determining Abundance and Occurrence of Leaf-Miners" (see Diškus, Stonis 2012: 52-54), Stigmella auripurpurata is not a rare species: rather abundant mining of the new species was observed in two separated localities of the equatorial Andes in Ecuador.

Distribution (Figs. 1, 3). This species occurs in the Ecuadorian Andes in tropical montane and cloud forests at altitudes ca. 2900-3100 m, however, similar leaf-mines were observed also in lower altitudes (around $2000 \mathrm{~m}$ ).

Etymology. The species name is derived from the Latin aurea (gold, golden) and purpuratus (purple) in reference to the distinctive golden gloss and strong purple iridescence of the forewing.

\section{Documentation of specific leaf-mines of un- described Stigmella taxon on Phenax hirtus} Leaf-mine sample examined. Leaf-mines (no adults), ECUADOR: Pichincha Province, $11 \mathrm{~km}$ NW Alóag, 0²6’12”S, 78³7’24"W, elevation $3140-3165 \mathrm{~m}$, mining larvae on Phenax hirtus, 24.ii.2007, A. Diškus.

Documentation. Mines in leaves. Host plant: Phenax hirtus (Sw.) Wedd. (Urticaceae)

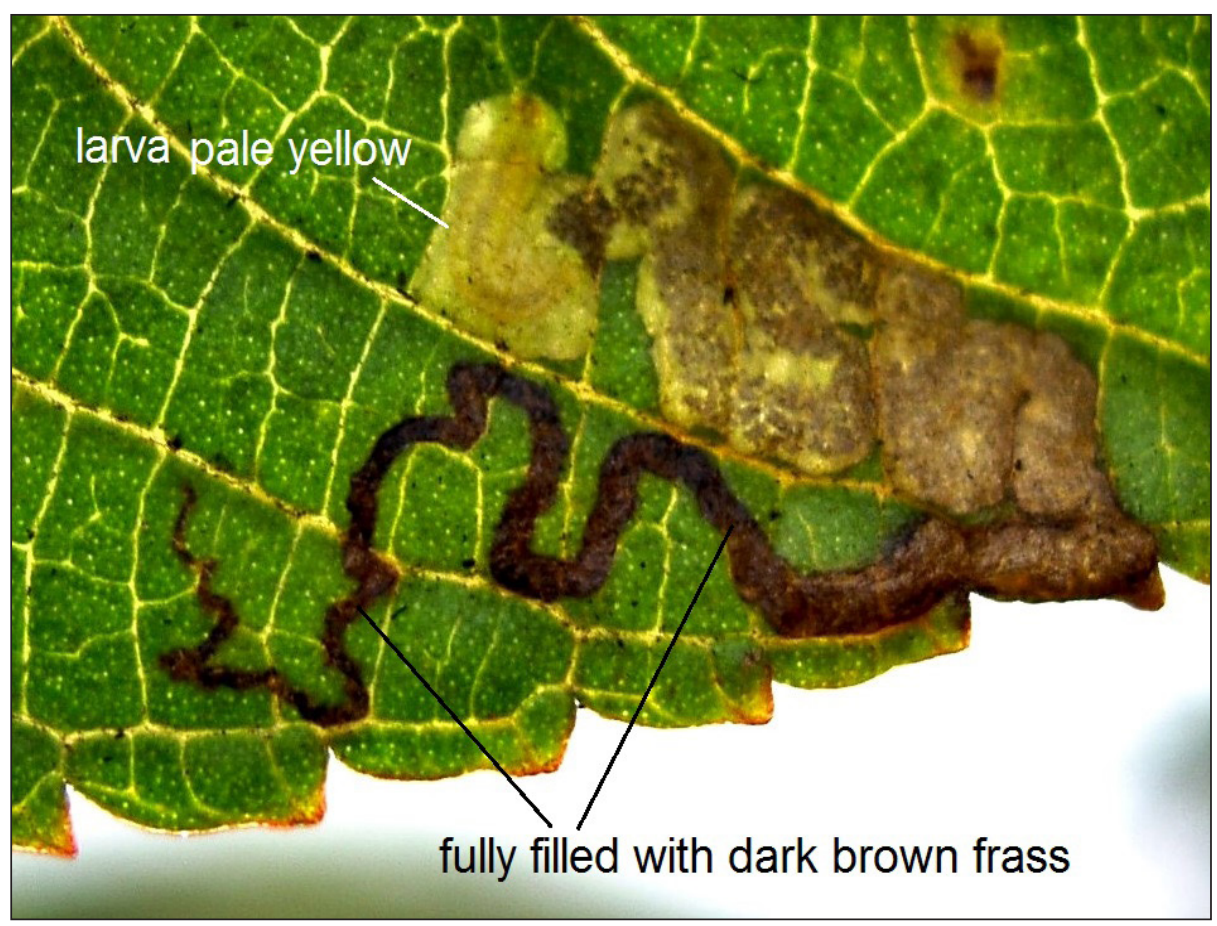

Fig. 64. Documented leaf-mine of undescribed Stigmella taxon from Phenax hirtus, Ecuador: Pichincha Province, 11 km NW Alóag, 0²6’12”S, 78³7’24”W, elevation 3140-3165 m 
(Figs. 4-7). Larvae pale yellow green with pale, ochreous brown intestine and pale brown head; mine in early February and, judging on observed empty leaf-mines, also in January. Leaf-mine as a gradually widening sinuous or contorted gallery fully filled with brown frass (dark brown in the first half and greyish brown in the second half) (Fig. 64). This unknown species occurs on the western slopes of the equatorial Andes (Ecuador) at altitudes about 3100 m (Fig. 3).

Remarks. The documented, highly specific leaf-mines on Phenax hirtus belong to an unknown (new) Stigmella species. However, no pupae or adults were available.

\section{DISCUSSION}

Urticaceae-feeding fauna worldwide. In the world, the Urticaceae-feeding Nepticulidae are known from only 12 records, representing five described and seven undescribed species of the pygmy moth family. In South America, Urticaceae-mining Nepticulidae are from six records, representing specific leaf-mines of an unknown taxon and four named species: Stigmella singularia Diškus \& Stonis, sp. nov., S. lata Diškus \& Stonis, sp. nov., S. boehmeriphaga Diškus \& Stonis, sp. nov., and S. auripurpurata Diškus \& Stonis, sp. nov.

Generic composition of this Urticaceaefeeding fauna is very uniform: all species belong to the genus Stigmella Schrank. The dominance of Stigmella among the Urticaceae-feeders in South America is not an artifact as it is in the case of species feeding on Rosaceae (Stonis et al., 2016b), Asteraceae (Stonis et al., 2016a, 2016c, 2017b), or Lamiaceae (Stonis et al., in prep.). The genus Stigmella is the world's most widespread and diverse group of Nepticulidae, occurring in very different habitats. Among the discovered Stigmella species associated with Urticaceae, the three species (Stigmella singularia and $S$. lata particularly) are very similar and therefore likely to be closely related. For diagnostic purposes, two species groups, S. singularia and S. marmorea, were designated.

\section{What makes Urticaceae-feeding Nepticu- lidae unusual:}

1. Low diversity. Following a recent preliminary trophic review of Nepticulidae (Remeikis et al., 2016), 24 plant families and 16 plant orders were documented as host-plant clades for the Nepticulidae, occurring in America, south of Nearctic Mexico. In the Neotropical fauna, some host-plant families are more common than others: Asteraceae (Compositae) account for $23.7 \%$ of documented Nepticulidae taxa; Rosaceae for $15.3 \%$, Lamiaceae for $12.7 \%$, Fagaceae for $8.5 \%$, Euphorbiaceae for 5.1\%, and Fabaceae and Malvaceae, for $4.2 \%$ (respectively). The documented Urticaceaefeeding Nepticulidae form only a small fraction of the Neotropical taxa (about 3\%). We assume that the relatively low number of species trophically associated with Urticaceae plants is not an artifact of insufficient sample effort. There should therefore be some other, so far unknown, causes.

2. Currently known pattern of distribution. It is surprising that all known records of the Urticaceae-feeding Nepticulidae come from regions around the Pacific (Fig. 1).

3. Host plant choice. Nepticulidae colonise at least three of the four Urticaceae tribes (Fig. 2). To date, this includes six genera: Boehmeria (four nepticulid species: two described/ named, one undescribed and one unknown taxon known from old herbaria specimen, Figs. 65, 66), Oreocnide (one undescribed species), Pipturus (one described/named species), Pilea (one described/named species), Phenax (two described/named and one unknown taxon judging from the documented leaf-mines; Fig. 64), and Moutia (one unknown taxon judging from the documented leaf-mines). With the exception of Pilea and Maoutia, all these belong to the Boehmerieae. Of note, none colonize genera in the Urticeae tribe which is characterized by stinging hairs. It would be interesting to know why no leaf-miners were found on other genera.

Phenax, Boehmeria and Pilea are all widespread genera, the former two pantropical and the latter pantropical with the exception of Australasia. Phenax and Boehmeria are woody 


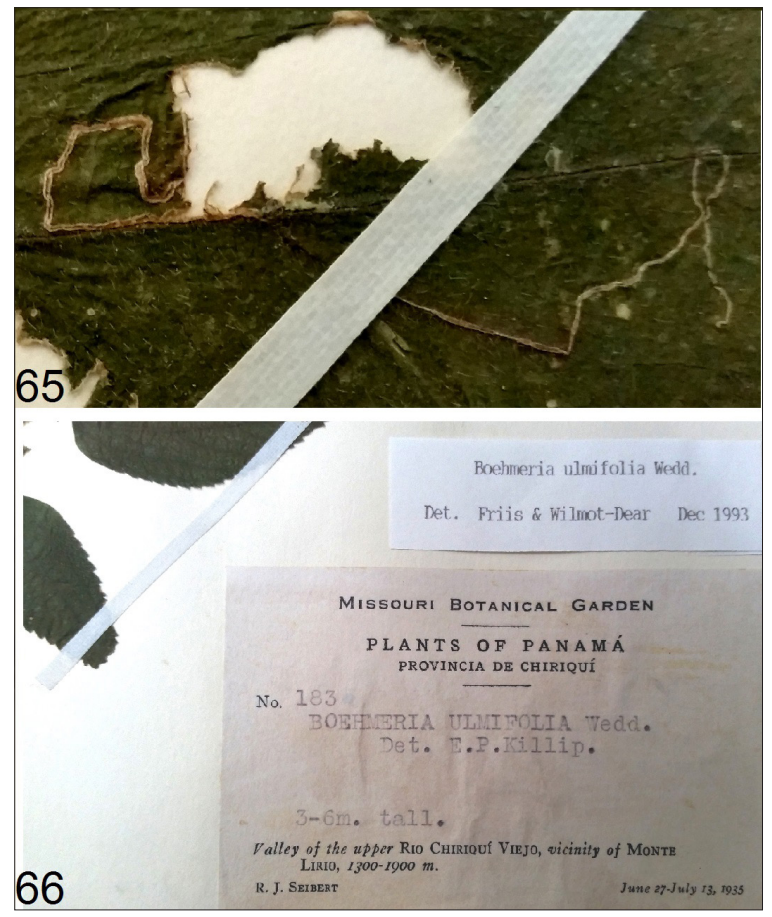

Figs. 65, 66. An unknown, probably Stigmella taxon tracked on herbarium specimen of Boehmeria ulmipholia collected in Panama in 1935 (the Royal Botanic Gardens, Kew). 65 - leaf-mine, 66 - label of the herbarium specimen

shrubs or trees, specialist of disturbed habitats and fall within the Boehmerieae tribe (Weddell, 1869). Pilea comprises succulent herbs, epiphytes or shrubs, is a specialist of undisturbed shade habitats, and has been placed in the Elatostemeae tribe (Wu et al., 2013).

Using herbaria to search for Urticaceaefeeding Nepticulidae. During the preparation of the manuscript we searched for Nepticulidae leaf-mines on Urticaceae in the herbarium of the Royal Botanic Gardens, Kew. So far we were able to review only a relatively small portion of the herbarium specimens but covered Neotropical Discocnide, Urera and Asian Poikilospermum (Urticeae), Neotropical Poulzolzia and Boehmeria (Boehmerieae). This search resulted in the discovery of a linear leaf-mine belonging to an unknown Stigmella species. The leaf-mine, though damaged, was tracked on Boehmeria ulmifolia Wedd. collected in Panama in 1935 (Figs. 65, 66). This discovery of a leaf-mine showed that using herbarium specimens is a practical way of discovering leaf-mines. Whilst species cannot be described from the leaf-mine alone, a review of herbarium specimens may yield additional data on insect-plant interactions, diversity, and their geographical distribution.

\section{ACKNOWLEDGEMENTS}

We are indebted to Ole Karsholt and the late Professor Niels P. Kristensen (ZMUC) for the initial stimulus to start the Neotropical project together with generous support during its course as well as the loan of the Neotropical material. For helpful and frequent discussions on various host-plant plants (not only those which are listed in the current paper) we thank: Arvind Singh (Banaras Hindu University, Varanasi, India), Narayanan Nair Mohanan (Jawaharlal Nehru Tropical Botanic Garden and Research Institute, India), José Luis Fernández-Alonso (Universidad de Salamanca, Spain), Theodor C. H. Cole (Universität Heidelberg, Germany), Maximilian Weigend (University of Bonn, Germany), and Franz Starlinger (Federal Research and Training Centre for Forests, Natural Hazards and Landscape, Vienna, Austria).

This study was supported by the Research Foundation of the Lithuanian University of Educational Sciences (2017). Andrius Remeikis is grateful for the research stipend in 2017 from the Research Foundation of the Research Council of Lithuania.

Received 12 February 2017 Accepted 20 March 2017

\section{References}

1. Diškus A, Stonis JR. Leaf-mining insects of Lithuania. The Nepticulidae (Lepidoptera): taxonomy, chorological composition and trophic relationships [monograph]. Kaunas: Lutute Publishers. 2012. 220 p.

2. Johansson R, Nielsen ES, van Nieukerken EJ, Gustafsson B. The Nepticulidae and 
Opostegidae(Lepidoptera) of North West Europe. Fauna Entomol. Scand. 1990; 23(1/2): 1-739.

3. Kemperman TC, Wilkinson C. Japanese species of the genus Stigmella (Nepticulidae: Lepidoptera). Insecta Matsumurana. 1985; 32: 1-107.

4. Kuznetzov VI, Puplesis R. Sem. Nepticulidae (Stigmellidae) - moli-malyutki. In: Kuznetzov, VI, editor. Nasekomye i kleshchi - vrediteli sel'skokhozyaistvennykh kul'tur. Cheshuekrylye [Insects and mites - pests of agricultural plants. Lepidoptera]. 1994; 3(1): 12-23. Nauka Publishers, St. Petersburg. Russian.

5. Puplesis R. The Nepticulidae of Eastern Europe and Asia: western, central and eastern parts. Leiden: Backhuys Publishers. 1994. 291 p.

6. Puplesis R, Diškus A. The Nepticuloidea \& Tischerioidea (Lepidoptera) - a global review, with strategic regional revisions. Kaunas: Lututè Publishers. 2003. 512 p.

7. Puplesis R, Diškus A, Robinson GS. New Neotropical Nepticulidae (Lepidoptera) from the western Amazonian rainforest and the Andes of Ecuador. Bull Nat Hist Mus Entomol. 2002a; 71(1): 19-58.

8. Puplesis R, Diškus A, Robinson GS, Onore G. A review and checklist of the Neotropical Nepticulidae (Lepidoptera). Bull Nat Hist Mus Entomol. 2002b; 71(1): 59-76.

9. Puplesis R, Robinson GS. A review of the Central and South American Nepticulidae (Lepidoptera) with special reference to Belize. Bull Nat Hist Mus Entomol. 2000; 69(1): 3-114.

10. Remeikis A, Diškus A, Stonis JR. Preliminary trophic analysis of leaf-mining Nepticulidae: pronounced feeding strategies in Middle and South America? Biologija. 2016; 62(4): 207-214.

11. Scoble MJ. A revised cladistic classification of the Nepticulidae (Lepidoptera) with descriptions of new taxa mainly from South Africa. Transv Mus Monograph. 1983; 2: i-xi, 1-105.

12. Stonis JR, Diškus A, Paulavičiūtè B, Monro AK. Urticaceae-feeders from the family Tisch- eriidae: descriptions of two new species and new genus Paratischeria gen. nov. Biologija. 2017a; 63 (1): 1-22.

13. Stonis JR, Diškus A, Remeikis A, Davis DR, SolisvMA, Cumbicus Torres N. The first record of Baccharis L. (Asteraceae) as a host-plant genus for Nepticulidae (Lepidoptera), with description of new Stigmella species from South America. Zootaxa. 2016a; 4136(1): 101-28.

14. Stonis JR, Diškus A, Remeikis A, Cumbicus Torres N. Rosaceae-feeding Nepticulidae (Lepidoptera) of South America: some taxonomic and trophic diversity revealed. Biologija. 2016b; 62(4): 215-32.

15. Stonis JR, Diškus A, Remeikis A, Gerulaitis V, Karsholt O. Leaf-mining Nepticulidae (Lepidoptera) from record high altitudes: documenting an entire new fauna in the Andean páramo and puna. Monograph. Zootaxa. 2016c; 4181(1): 1-94.

16. Stonis JR, Diškus A, Remeikis A, Karsholt O. Do leaf-mining Nepticulidae occur in the natural but so threatened Andean Polylepis forests? Biologija. 2016d; 62(2): 83-97.

17. Stonis JR, Diškus A, Remeikis A, Karsholt O, Cumbicus Torres N. Illustrated review of the leaf-mining Nepticulidae (Lepidoptera) of the central Andes (Peru and Bolivia). Zootaxa. 2017b; 4257 (1): 1-70.

18. Stonis JR, Diškus A, Remeikis A, Navickaitė A. Study methods of Nepticulidae: micro-mounts of genitalia structures. In: Stonis JR, Hill SR, Diškus A, Auškalnis T, editors. Selected abstracts and papers of the First Baltic International Conference on Field Entomology and Faunistics. Vilnius: Edukologija Publishers. 2014. p. 32-35.

19. Stonis JR, Diškus A, Remeikis A. The first description of the leaf-mining Nepticulidae (Lepidoptera) feeding on the South American plant genus Liabum, Asteraceae. Zootaxa. 2015; 4040(5): 576-82.

20. Van Nieukerken EJ, van den Berg C. A new Stigmella feeding on Urticaceae from Guam: first records of Nepticulidae (Lepidoptera) 
from Micronesia and Polynesia. Invertebrate Systematics. 2003; 17: 27-37.

21. Van Nieukerken EJ, Doorenweerd C, Nishida K, Snyers C. New taxa, including three new genera show uniqueness of Neotropical Nepticulidae (Lepidoptera). ZooKeys. 2016; 628: 1-63.

22. Weddell HA. Urticacées. In: Candolle AD (Ed.), Prodromus Systematis Naturalis Regni Vegetabilis. 1869, Victoris Masson et Filii, Paris, pp. 32-235.

23. Wu Z-Y, Monro AK, Milne IR, Wang $\mathrm{H}$, Yi T-S, Liu J, Li D-Z. Molecular phylogeny of the neetle family (Urticaceae) inferred from multiple loci of three genomes and extensive generic sampling. Molecular Phylogenetics and Evolution. 2013; 69: 814-27.
Jonas Rimantas Stonis, Arūnas Diškus, Andrius Remeikis, Alex K. Monro

PIRMĄ KARTĄ PIETŲ AMERIKOJE APTIKTŲ URTICACEAE AUGALŲ MINUOTOJŲ, PRIKLAUSANČIŲ NEPTICULIDAE (LEPIDOPTERA), DOKUMENTACIJA: KETURIOS NAUJOS MAŽŲJŲ GAUBTAGALVIŲ RŪŠYS, TROFIŠKAI SUSIJUSIOS SU PHENAX, BOEHMERIA IR PILEA AUGALAIS

\section{Santrauka}

Šiame straipsnyje pirmą kartą skelbiami duomenys apie Urticaceae šeimos augalus minuojančius mažuosius gaubtagalvius Pietų Amerikoje. Aprašomos keturios naujos rūšys: dvi iš jų mitybos ryšiais yra susijusios su Phenax Wedd. genties augalais (Stigmella singularia Diškus \& Stonis, sp. nov. ir S. lata Diškus \& Stonis, sp. nov.), viena - su Boehmeria Jacq. gentimi (S. boehmeriphaga Diškus \& Stonis, sp. nov.) ir viena nauja mažuju gaubtagalvių rūšis - su Pilea Lindl. gentimi (S. auripurpurata Diškus \& Stonis, sp. nov.). Visos šios rūšys rastos Pietų Anduose. Iki šiol nedaug Urticaceae minuotojų buvo žinoma iš Japonijos, Pietryčiu Azijos ir Okeanijos salų. Straipsnyje taip pat dokumentuotos specifinès minos, aptiktos ant Phenax augalų lapų, kurios priklauso iki šiol dar neaprašytai naujai Stigmella genties rūšiai. Morfologijos ir taksonomijos požiūriu Pietų Amerikoje aptikti Urticaceae augalų minuotojai šiek tiek skiriasi, todèl priskirti dviem Stigmella rūšių grupèms: S. singularia ir S. marmorea (pastaroji pirmą kartą išskirta ir ivardyta šiame straipsnyje).

Raktažodžiai: Andai, Boehmeria Jacq., lapụ minos, mažieji gaubtagalviai, naujos rūšys, Nepticulidae, Pilea Lindl., Pietų Amerika, Phenax Wedd., Stigmella Schrank, Urticaceae 